\title{
PERKEMBANGAN ARENA KAJIAN ANTROPOLOGI HUKUM
}

\author{
Nama Mahasiswa : Riski Mulliadi \\ Email : : Riskimulliadi02@gmail.com \\ No BP $\quad$ : 2110003600300 \\ Kelas : 1 H7 \\ Perguruan Tinggi : UNES
}

\section{A. PENDAHULUAN}

Antropologi hukum adalah kajian antropologis terhadap makna sosial dari dan pentingnya hukum dengan menelaah bagaimana hukum dibuat termasuk bagaimana konteks sosial pembuatan hukum tersebut, bagaimana hukum mempertahan kan dan mengubah institusi sosial lainnya, dan bagaimana hukum membangun perilaku sosial.] Namun seiring perkemba ngan zaman dan tatanan politik dunia pasca-Perang Dingin, cakupan kajian antropologi hukum meluas di antaranya membahas keterkaitan antara konflik sosial dengan kesenjang an ekonomi dan batasan-batasan hukum dalam melakukan rekayasa sosial. Antropologi hukum kini turut mengkaji hubun an antara politik dan hukum yang juga berubah dalam konteks pasca-Perang Dingin tersebut.

Sebagai akibat dari perluasan cakupan tersebut, bahkan ada kalangan yang menyebut kajian antropologi hukum pada abad ke-19 sebagai kajian antropologi protolega Pengertian lain tentang hukum yaitu bahwa hukum diartikan sebagai proses pemerintahan. Proses pemerintahan itu mencangkup peraturan, pemerintahan dalam artisempit,penanggula ngan serta peradilan.Hukum diartikan pula sebagai jalinan nilai. Nilaitersebut merupakan konsepsi abstrak di dalam diri manusia mengenai apa yang dianggap baikserta apa yang dianggap buruk. Hukum diartikan sebagai nilai yang merupakan salah satu unsur pandangan manusia mengenai hal-hal yang seharusnya dianuti karena dianggap baik,dan hal-hal yang seharusnya dihindari karena dianggap buruk 


\section{B. PEMBAHASAN}

\section{Pengertian antapologi hukum}

Pembagian Antropologi hukum Antropologi mempelajari perkembangan kehidupan manusia dan budayanya,dengan cabang-cabang ilmu, diantaranya; ilmu PraSejarah untuk mempelajari kehidupan asal usul manusia, dan untuk mengetahui ragam bahasa manusia maka harus mempelajari Etnolinguistik, sedangkan ilmu yang mempelajari cara manusia berbangsa dan berbudaya disebut Etnologi.Antropologi adalah studi ilmu yang mempelajari tentang manusia dari Aspek Budaya, Perilaku, Nilai, Keanekaragaman, dan lainnya.Antropologi terbagi dalam: Antropologi Ekonomi, Antropologi Politik, Antropologi Pendidikan, dan Antropologi Hukum. Antropologi Hukum merupakan ilmu yg mempelajari manusia dengan kebudayaan, khususnya di bidang Hukum, atau ilmu tentang Manusia dalam kaitannya dengan Kaidah-kaidah sosial yang bersifat Hukum.

\section{Pembagian Antropologi hukum}

Antropologi mempelajari perkembangan kehidupan manusia dan budayanya,dengan cabang-cabang ilmu, diantaranya; ilmu PraSejarah untuk mempelajari kehidupan asal usul manusia, dan untuk mengetahui ragam bahasa manusia maka harus mempelajari Etnolinguistik, sedangkan ilmu yang mempelajari cara manusia berbangsa dan berbudaya disebut Etnologi.Antropologi adalah studi ilmu yang mempelajari tentang manusia dari Aspek Budaya,Perilaku, Nilai, Keanekaragaman, dan lainnya. Antropologi terbagi dalam: Antropologi Ekonomi, Antropologi Politik, Antropologi Pendidikan, dan Antropologi Hukum. Antropologi Hukum merupakan ilmu yg mempelajari manusia dengan kebudayaan, khususnya di bidang Hukum, atau ilmu tentang Manusia dalam kaitannya dengan Kaidah-kaidah sosial yang bersifat Hukum.

\section{Hubungan Budaya Dan Kebudayaan Hukum}

Hukum sangat berkaitan erat dengan kebudayaan. Hukum sendiri merupakan produk kebudayaan, karena sejatinya produk hukum adalah produk ciptaan manusia. Dalam studi hukum dikenal struktur hukum, substansi hukum, dan budaya 
hukum. Hukum diciptakan memiliki karakteristik yang berbeda-beda dari satu daerah ke daerah lainnya sesuai dengan kebudayaan setempat. Artinya, kebudayaan membentuk hukum. Menurut Prof. Tjip, hukum itu bukanlah skema yang final, tetapi terus bergerak sesuai dengan dinamika dan perkembangan zaman umat manusia. Artinya,hukum akan terus berubah sesuai dengan perkembangan zaman dan dinamika manusia ini terlahir dalam proses kebudayaan yang berbeda. Kebudayaan yang terdapat dalam masyarakat terlibat dalam hal pembentukan hukum. Di Indonesia dikenal adanya masyarakat Hukum Adat yang jumlahnya sangat banyak. Perkembangan kebudayaan dan hukum menciptakan suatu subjek hukum yang bernama Hukum Adat. Dalam Pendidikan Tinggi hukum, terdapat mata kuliah yang kaitannya dengan Hukum, Masyarakat, dan Kebudayaan: Hukum Adat,Antropologi Hukum, Hukum dan Masyarakat, dan Sosiologi Hukum. Mata kuliahmata kuliah inilah adalah awal pengenalan mahasiswa hukum terhadap hubungan dari hukum dan kebudayaan.Bahwa kebudayaan memiliki peran penting terhadap eksistensi hukum.Dimensi kebudayaan ini masuk kedalam norma-norma hukum. Hal ini terjadi denganadanya Hukum Adat yang lebih sempit lagi melahirkan konsep-konsep hak tanah atas masyarakat adat yang lebih sering dikenal sebagai hak ulayat. Kebudayaan juga memberi ruang dalam proses penyelesaian perkara secara informal, seperti yang terjadi dalam masyarakat Kpelle di Liberia Tengah, Afrika. Kebudayaan hadir dimana-dimana, dan membentuk sebuah pemahaman hukum yang sifatnya pluralis.

\section{Arena kajian Antropologi hukum}

Kajian Antropologi Hukum adalah menggali norma dan nilai-nilai dalam masyarakat.Arena Antropologi Hukum mempelajari manusia dan budaya hukum, karenanya kaidah sosial yang tidak bersifat hukum bukanlah sasaran pokok penelitian Antropologi Hukum.Norma / kaidah menurut Antropologi Hukum pola ulangan perilaku dalam masyarakat.Norma / Kaidah adalah nilai dasar yang ada dalam masyarakat yang dapat mengukur perilaku manusia agar dapat menilai mana perbuatan benar dan mana yang tidak benar.Norma memiliki aspek hukum ketika 
aparat menjatuhkan sanksi karena ada perbuatan yang menyimpang atau melanggar hukum Sanksi bersifat positif seperti dengan membayar denda atau kerja sosial, dan sanksi bersifat negatif seperti hukuman badan atau dikucilkan..Hukum muncul dari peradaban manusia, dimana ada 2 orang atau lebih di situ ada hukum.

\section{Sifat keilmuan antropologi hukum}

a) Antropologi Hukum tidak membatasi pandangan pada kebudayaan tertentu (studi perbandingan).

b) Antroplogi Hukum, mempelajari masyarakat sebagai suatu keseluruhan yang utuh, dimana bagian-bagiannya saling bertautan.

c) Antropologi Hukum Modern tidak memusatkan perhatian hanya pada kekuatan sosial dan hal superorganis.

d) Antropologi Hukum memandang masyarakat secara Dinamis, sehingga peranan sosial dan Hukum tidak terbatas mempertahankan status quo

e) Antropologi Hukum termasuk ilmu Hukum yang empiris.

\section{Ruang Lingkup Antropologi Hukum}

Ruang Lingkup Antropologi Hukum adalah suatu spesialisasi dari Antropologi Budaya, Antropologi Sosial, dan Kebudayaan Hukum yang menyangkut Aspekaspek Hukum.Laura Nader dalam bukunya "The Anthropological Study of Law"( 1965 ),mengemukakan masalah pokok yang merupakan ruang lingkup Antropologi Hukum sebagai berikut:

a) Apakah dalam setiap masyarakat terdapat Hukum dan bagaimana karateristik Hukum yg Universal?

b) Bagaimana Hubungan antara Hukum dengan aspek kebudayaan dan organisasi sosial?

c) Apakah mungkin diadakan Tipologi Hukum tertentu sedangkan variasi karakteristik hukum terbatas?

d) Apakah Tipologi Hukum berguna untuk menelaah hubungan antara Hukum dengan Aspek Budaya dan organisasi sosial. 
e) Mengapa Hukum itu berubah, setrta bagaimana cara mendeskripsikan Sistemsistem Hukum?

\section{7. kajian antropologi hukum dengan ilmu sosial lainya}

Di dalam perkembangan antropologi, masalah hukum sebenarnya juga sudah pernah ditelaah, walaupun di dalam suatu kerangka kebudayaan yang serba luas.Sarjana-sarjana antropologi seperti Barton, Radcliffe-Brown, Malinowski dan lainnya,pernah memusatkan perhatian pada hukum sebagai suatu gejala sosialbudaya.Menurut Ihromi (1986; 3) relevansi.

menelaah hukum dari segi antropologi, antara lain adalah: (a). Berkenaan dengan masalah yang dihadapi oleh negara-negara berkembang (tentunya termasuk Indonesia) yang secara budaya bersifat pluralistis dalam cita-citanya mewujudkan unifikasi hukum atau modernisasi hokum; (b). berkenaan dengan kemungkinan munculnya masalah bila warga masyarakat dari lingkungan sukubangsa tertentu masih mempunyai norma-norma tradisional yang kuat dan menuntut ketaatan mengenai hal-hal tertentu, sedangkan dalam norma hukum yang sudah tertulis dan berlaku secara nasional, hal- hal yang harus ditaati itu justru dirumuskan sebagai hal yang terlarang.

Secara faktual, masalah-masalah yang dirumuskan ke dalam dua point utama itu sudah terjadi, baik berkenaan dengan munculnya konflik horisontal di pelbagai wilayah, pertikaian antara state (maupun pemda) dengan masyarakat, maupun antar kelompok masyarakat sendiri. Hukum, menurut Benda-Beckmann (1979; 113-114) adalah suatu cara khusus untuk membatasi otonomi anggota-anggota masyarakat.Kebanyakan penulis menyetujui bahwa hukum adalah suatu bentuk pengawasan sosial, itulah mengapa secara esensial sifatnya normatif, dan hal itu merujuk pada apa yang disebut (sebagai) konsepsi- konsepsi yang obyektif.

Implikasi pendekatan semacam ini adalah: bahwa hukum memberi input kepada pranata pengendalian sosial (apapun variant-nya) dan kemudian kepada rujukan berpikir masyarakat, dan sebaliknya. Hukum, di sisi lain, dapat pula menyebabkan perubahan perangkat berpikir, dan rujukan kemasyarakatan lainnya atau dikenal 
dalam sosiologi hukum sebagai "law as tool of social engineering".Namun, bila kesemua hal itu berubah (dan pada kenyataannya memang selalu demikian), maka hukum pun berubah mengikuti perubahan masyarakat danlingkungannya. bidang ilmu lainnya, seperti dengan ilmu administrasi, Ilmu Politik, Ilmu Sejarah, dan sebagainya.

\section{PENUTUP}

Antropologi hukum adalah kajian antropologis terhadap makna sosial dari dan pentingnya hukum dengan menelaah bagaimana hukum dibuat termasuk bagaimana konteks sosial pembuatan hukum tersebut, bagaimana hukum mempertahan kan dan mengubah institusi sosial lainnya, dan bagaimana hukum membangun perilaku sosial.Pembagian Antropologi hukum Antropologi mempelajari perkembangan kehidupan manusia dan budayanya,dengan cabang-cabang ilmu, diantaranya; ilmu PraSejarah untuk mempelajari kehidupan asal usul manusia, dan untuk mengetahui ragam bahasa manusia maka harus mempelajari Etnolinguistik.

Arena Antropologi Hukum mempelajari manusia dan budaya hukum, karenanya kaidah sosial yang tidak bersifat hukum bukanlah sasaran pokok penelitian Antropologi Hukum.Norma / kaidah menurut Antropologi Hukum pola ulangan perilaku dalam masyarakat.Norma / Kaidah adalah nilai dasar yang ada dalam masyarakat yang dapat mengukur perilaku manusia agar dapat menilai mana perbuatan benar dan mana yang tidak benar. Di dalam perkembangan antropologi, masalah hukum sebenarnya juga sudah pernah ditelaah, walaupun di dalam suatu kerangka kebudayaan yang serba luas.Sarjana-sarjana antropologi seperti Barton, Radcliffe-Brown, Malinowski dan lainnya,pernah memusatkan perhatian pada hukum sebagai suatu gejala sosial-budaya.Menurut Ihromi $(1986 ; 3)$ relevansi. 


\section{DAFTAR PUSTAKA}

Darmini Roza dan Laurensius Arliman S, Peran Pemerintah Daerah Di Dalam Melindungi Hak Anak Di Indonesia, Masalah-Masalah Hukum, Volume 47, Nomor 1, 2018. https://doi.org/10.14710/mmh.47.1.2018.10-21

Laurensius Arliman S, Peranan Metodologi Penelitian Hukum di Dalam Perkembangan Ilmu Hukum di Indonesia, Soumatera Law Review, Volume 1, Nomor 1, 201. http://doi.org/10.22216/soumlaw.vli1.3346.

Laurensius Arliman S, Peran Badan Permusyawaratan Desa di Dalam Pembangunan Desa dan Pengawasan Keuangan Desa, Padjadjaran Journal of Law, Volume 4, Nomor 3, 2017. https://doi.org/10.15408/jch.v4i2.3433.

Laurensius Arliman S, Penanaman Modal Asing Di Sumatera Barat Berdasarkan UndangUndang Nomor 25 Tahun 2007 Tentang Penanaman Modal, Supremasi Hukum, Volume 1, Nomor 1, 2018. http://dx.doi.org/10.36441/hukum.v1i01.102.

Laurensius Arliman S, Memperkuat Kearifan Lokal Untuk Menangkal Intoleransi Umat Beragama Di Indonesia, Ensiklopedia of Journal, Volume 1, Nomor 1, 2018, https://doi.org/10.33559/eoj.v1i1.18.

Laurensius Arliman S, Perkawinan Antar Negara Di Indonesia Berdasarkan Hukum Perdata Internasional, Kertha Patrika, Volume 39, Nomor 3, 2017, https://doi.org/10.24843/KP.2017.v39.i03.p03.

Laurensius Arliman S, Partisipasi Masyarakat Di Dalam Pengelolaan Uang Desa Pasca Undang-Undang Nomor 6 Tahun 2014 Tentang Desa, Jurnal Arena Hukum, Volume 12, Nomor 2, 2019, https://doi.org/10.21776/ub.arenahukum.2019.01202.5.

Laurensius Arliman S, Mewujudkan Penegakan Hukum Yang Baik Di Negara Hukum Indonesia, Dialogica Jurnalica, Volume 11, Nomor 1, 2019, https://doi.org/10.28932/di.v11i1.1831.

Laurensius Arliman S, Mediasi Melalui Pendekatan Mufakat Sebagai Lembaga Alternatif Penyelesaian Sengketa Untuk Mendukung Pembangunan Ekonomi Nasional, UIR Law Review, Volume 2, Nomor 2, 2018, https://doi.org/10.25299/uirlrev.2018.vol2(02).1587

Laurensius Arliman S, Peranan Filsafat Hukum Dalam Perlindungan Hak Anak Yang Berkelanjutan Sebagai Bagian Dari Hak Asasi Manusia, Doctrinal, Volume 1, Nomor 2,2016.

Laurensius Arliman S, Ni Putu Eka Dewi, Protection of Children and Women's Rights in Indonesia through International Regulation Ratification, Journal of Innovation, Creativity and Change Volume 15, Nomor 6, 2021. 
Laurensius Arliman S, Gagalnya Perlindungan Anak Sebagai Salah Satu Bagian Dari Hak Asasi Manusia Oleh Orang Tua Ditinjau Dari Mazhab Utilitarianisme, Jurnal Yuridis, Volume 3, Nomor 2, 2016, http://dx.doi.org/10.35586/.v3i2.180.

Laurensius Arliman S, Tantangan Pendidikan Kewarganegaraan Pada Revolusi 4.0, Jurnal Ensiklopedia Sosial Review, Volume 2, Nomor 3, $2020 .$. 